\section{Military Technical College Kobry El-Kobbah, Cairo, Egypt}

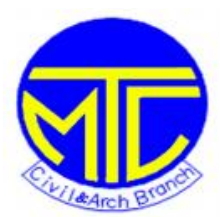

\title{
THE FEASIBILITY OF PROTECT REBARS AGAINST CORROSION USING LOCALLY AVAILABLE MATERIALLS IN EGYPT
}

\author{
$9^{\text {th }}$ International Conference \\ on Civil and Architecture \\ Engineering \\ ICCAE-9-2012
}

\author{
ALaa A. Bashandy ${ }^{*}$
}

\begin{abstract}
Steel-reinforced concrete is widely used in construction. The corrosion of the steel reinforcing bars (rebars) in concrete limits the service life of concrete structures. Corrosion is one of the main causes for the deterioration of the civil construction and infrastructure. Efficiency of using reinforcing bars coating materials to reduce the effect of water and salt solutions on the steel reinforcement in concrete to extend the life of reinforced concrete structures was investigated in this ex perimental program. In this study, the concrete used had a compressive strength of $25.5 \mathrm{MPa}$. Steel rebars were first coated with locally available painting materials in Egypt to investigate the feasibility of protect against environmental effect as chlori de attack then, the rebars as well as embedded rebars in concrete were immersed in $5 \%$ concentration $\mathrm{NaCL}$ solution for 3 months to investigate the corrosion effect by using the bond test before and after chloride attack and rust performing.
\end{abstract}

Keywords: Coating; Steel; Reinforcement; Corrosion; Ductility.

\section{INTRODUCTION}

Steel reinforced concrete used in structures gives strength and durability by having to bear both the tensile and compressive strength; whereas, the strength and durability vary depending upon the concrete and steel properties.

The bonding of the reinforcing steel with concrete is essential to allow transfer of load between these two components. The bond strength depends upon the types of rebar; ribbed or smooth due to the three different me chanisms: chemical adhesion, friction and mechanical interlocking. Among them, ribbed reinforcing has better bonding with the concrete surface due to increased friction and mechanical interlocking. As the corrosion products increase, the bonding capacity is increased for the smooth rebar until the cracking of concrete. The bonding of the ribbed rebar with the concrete can be increased to a certain extent, although bonding between the concrete and the reinforcing steel will be damaged in both cases [1].

Steel in concrete are protected by a microscopic oxide passive layer of film. The $\mathrm{pH}$ of the pore water in concrete is normally in the range $12-13$ and thus steel is passive. Passive state is the state of the metal when the corrosion products form a prot ective film, limiting the rate of corrosion. The type of corrosion that mainly influences the surface of the steels in concrete is pitting corrosion, in which the passive film is destroyed locally and pits are formed on the surface of the steel. This passive layer can be broken down due to carbonation of concrete or

* Lecturer, Civil Engineering Department, Faculty of Engineering, Menoufiya University. 
by the action of chloride ions. Carbonation is confined to the surface layer of concrete and steel is protected by providing adequate depth of cover. If the $\mathrm{pH}$ of the concrete drops below 9 or if the total chloride content exceeds a critical value called chloride threshold, the passive film and the corrosion protection will be lost. Corrosion products which is basically an iron oxide is having a bigger volume than the original volume of affected steel and thus the formation of corrosion products exert an outward bursting pressure, which results to cracks and deterioration of durability.

This reduces the strength along with the formation of reaction products in the form of rusts. Passivity can be broken at critical chloride concentration depending upon the potentials of the steels [2].

Corrosion problems in different constructions, especially water structures such as water tanks and also in highway bridges, suggested the use of suitable protection methods of reinforcing rebars. Steel rebars provides the most suitable characteristics for the most applicable types of concretes. Corrosion of steel in concrete structures occurs mainly due to lack of protection where the concrete cover is not adequate. F or corrosion to occur, an electrochemical cell must be present. A cell consists of an anode and a cathode, separated by an electrolyte, and connected by a metallic conductor [3]. The anode is the area in which oxidation occurs, or where electrons are released. The cathode is the area where reduction occurs, where electrons are consumed [4]. The electrolyte is generally an aqueous solution that can carry ions, such as salt water, or, in concrete, alkaline pore solution [3]. Corrosion occurs in the steel rega rdless of the inherent capacity of concrete to protect the steel from corrosion; accelerated corrosion results from the loss of alkalinity in the concrete or the penetration of aggressive ions (such as chloride ions).

Corrosion of steel induced by chlorides is the major cause of damage of reinforced concrete structures exposed to seawater. There are many different ways in which chloride ions can be introduced to a reinforced concrete structure such as get into the concrete mix in an admixture or in contaminated aggregates or mix water, or they can diffuse into hardened concrete from external sources such as salt water or deicing salts. Because only the chloride ions that remain in solution are free to directly disrupt the passive layer on the reinforcement, the corrosion threshold will be higher for concrete in which chloride ions were introduced in the mix than for concrete that was exposed to chloride ions after hardening [5].

Chlorides penetrate the concrete cover and lead to the onset of pitting corrosion when their concentration near the steel surface reaches a critical threshold [6]. This threshold is not easy to evaluate, since it depends on several factors related both to the concrete and the environment [7]. In any case, it has been well established that the critical value increases if the potential of steel is lowered [8]. For this reason, corrosion hardly ever initiates in the parts of reinforced concrete structures that are permanently immersed in seawater, since lack of oxygen leads to very negative values of potential. Furthermore, even when corrosion initiates, the corrosion rate is negligible because of the small amount of oxygen that can reach the steel surface [6]. Critical conditions for corrosion initiation and subsequent propagation are usu ally found in the emerged part of structures (tidal and splash zones), where wetting and drying cycles favor the presence of both oxygen and chlorides. In calm seas with low tides (such as the Mediterranean sea), the most severe attacks are usually found within a couple of meters above the sea level; conversely, in agitated seas with high tides, serious corrosion attacks can occur at over $10 \mathrm{~m}$ above the sea level $[7,8,9]$.

Corrosion of steel reinforcing bars may controlled by two main methods. The first me thod was performed by protect steel rebars while the second was performed by convert concrete to impermeable material. 
The protection of steel rebars was performed by surface treatment of the rebars by protective coatings on the steel surface. Organic, epo xy coatings, serving as a barrier against the chloride ion attack and an electrical isolator against the flow of corrosion current, became the most popular method of protection in the United States. The coating of a steel rebar with epoxy is commonly used to improve corrosion resistance, but it degrades the bond between rebar and concrete, and the tendency of the epoxy coating to debond is a problem [10].

Converting concrete to impermeable material was performed by surface coating of concrete or by using admixtures (organic and inorganic corrosion inhib itors, silica fume [11], fly ash [12], slag and latex and the use of surface coating [13].

Other types of protection metal coatings, which are sacrificed during the corrosion process, can be also used. Zinc coatings, applied as hot-dip galvanizing, are the most favored method for civil engineering applications [14]. In chloride free concrete subjected to extensive carbonation, galvanized coating delays the onset of corrosion induced cracking [15]. However, if concrete contains over $1 \%$ of chloride by weight of cement intense corrosion of the zinc may occur [14]. Zinc coating should provide cathodic protection in areas with small defects, but can also produce localized corrosion of high rate if in contact with uncoated reinforcement.

Steel surface treatments that improve both corrosion resistance and bond strength are attractive. They include surface oxidation by immersion in water and sandblasting.

Surface oxidation means total immersion of the rebar in water at room temperature for two days. It causes the formation of a black oxide layer on the surface of the rebar, thus enhancing the composition uniformity of the surface and improving corrosion resistance. In addition, the oxide layer enhances the adhesion between rebar and concrete, thereby increasing bond strength. Water immersion times that are less than or greater than two days yield less desirable effects on both bond strength and corrosion resistance [16].

Sandblasting involves discharging ceramic partic les (typically alumina particles around 250

$\mathrm{m}$ ) under pressure (about $0.6 \mathrm{MPa}$ ). It results in roughening as well as cleaning the surface of the steel rebar due to the removal of rust and other contaminants on the surface. Cleaning causes the surface of the rebar to be more uniform in composition, which improves corrosion resistance. Roughening enhances the mechanical interlocking between rebar and concrete, thus increasing bond strength [16].

Steel rebars can also be coated with corrosion-inhibiting cement slurry or a cement-polymer composite for corrosion protection [17].

Of all the methods described for treating the surface of steel rebar, the most widely used are epoxy coating and galvanizing because of their long history of usage.

Admixtures are solids or liquids that are added to a concrete mix to improve the properties of the resulting concrete. Admixtures that enhance the corrosion resistance of steel reinforced concrete include those that are primarily for corrosion inhibition and those that are prima rily for improving the structural properties. The latter are attractive because of multi functionality. Admixtures primarily for structural property improvement can be solid particles such as silica fume [11], fly ash [12] and solid particle dispersions such as latex which improves corrosion resistance because it decreases water absorptive and increases electrical resistivity $[18,19]$.

Silica fume as an admixture is particularly effective for improving the corrosion resistance of steel-reinforced concrete due to the decrease in the water absorptive, and not so much because of the increase in electrical resistivity $[11,20]$.

Methylcellulose improves corrosion resistance only slightly Also carbon fibers decrease corrosion resistance due to a decrease in elec trical resistivity. However, the negative effect of the carbon fibers can be compensated by adding either silica fume or latex, which reduces 
water absorptive. The corrosion resistance of carbon fiber-reinforced concrete, which typically contains silica fume for improving fiber dispersion, is superior to that of plain concrete [20].

Instead of using a corrosion-inhibiting admixture in the entire volume of concrete, one may use the admixture to modify the cement slurry that is used as a coating on the steel rebar [21]. Compared to the use of rebars that have been either epoxy coated or galvanized, this method suffers from its labor-intensive site-oriented process. On the other hand, the use of a shop coating based on a cement-polymer composite is an emerging alternative [17].

Of all the admixtures described for improving the corrosion resistance of steel reinforced concrete, the most widely used are calcium nitrite, silica fume, and latex.

Surface coating on concrete can consider as a solution (such as acrylic rubber) can be applied to the concrete surface for the purpose of corrosion control through improving impermeability. However, this method suffers from the poor durability of the coating, and the loss of corrosion protection in areas where the coating is damaged [22].

Cathodic protection can be applied to control the corrosion rate [23, 24]. This is generally achieved using an extended anode laid on the surface of the concrete, either an inert anode (i.e. activated titanium) connected to a current feeder or a sacrificial anode (i.e. sprayed zinc). However, it was shown that, unless the concrete electrical resistivity is very low, protection provided by submerged anodes is of limited effectiveness above the waterline, so that other above surface systems are required [25, 26]. Since the early nineties, a technique called cathodic prevention has been developed to prevent the onset of pitting corrosion in new structures when, in time, chloride penetration from the environment takes place [27]. It consists in the application of a cathodic current to the passive reinforcement in uncarbonated and chloride free concrete. Cathodic prevention also differs from cathodic protection with regards to its throwing power. In fact, it has been shown that, in spite of the hig h resistivity of concrete, the beneficial effects of cathodic prevention can extend to rebars at remarkable distances from the anode [28]. This is a consequence of the higher cathodic polarizability of passive steel compared with corroding steel [29]. Conversely, effects of cathodic protection are usually limited to distances of a few tens of centimeters [28].

\section{RESEARCH SIGNIGICA NCE}

This research aimed to investigate the most suitable materials locally available in Egypt to protect the reinforcing steel bars (rebars) against corrosion. It also aimed to identify the extent of cohesion between the concrete and rebars insulated by different coating materials. Identical steel reinforcing bars are tested before and after corrosion attack. The importance of $t$ his research is based on current research needs knowing that the available data addressing the feasibility of using locally available protection materials in Egypt is scarce. This research provides important data for the site engineer concerning the efficiency of protecting steel reinforcing bars against corrosion. Also, possible valid protection materials and its impact on the bond strength between rebars and concrete in terms of bond strength are investigated.

\section{MATERIALS AND TEST SPECIMENS}

The experimental program was carried out by casting two groups of concrete cubic samples and group of steel rebars as follows, a total number of 3 cubic dimensions of $(15 \times 15 \times 15 \mathrm{~cm})$ to estimate the compressive strength of the concrete and 42 cubic dimensions of $(15 \times 15 \times 15 \mathrm{~cm})$ with embedded steel bars to evaluate the bond between concrete and 
reinforcement. The following sections provide detailed description of the materials used, description of test specimens and testing procedures.

\subsection{Materials}

Cement: The cement used was the ordinary Portland cement CEM I N32.5, from the Suez cement factory. Its chemical and physical characteristics satisfy the Egyptian Standard Specification (E.S.S. 4658-1/ 2005) [35].

Fine aggregate: The fine aggregate used in the experimental program was the natural siliceous sand. Its characteristics satisfy the Egyptian Code (E.S.S 1109/2008) [36]. It was clean and nearly free from impurities with a specific gravity $2.6 \mathrm{t} / \mathrm{m}^{3}$ and a fineness modulus of 2.52 .

Coarse aggregates: The coarse aggregate used was crushed dolomite, which satisfies the ASTM C33 Specification [37] with a specific gravity $2.70 \mathrm{t} / \mathrm{m}^{3}$ and a fineness modulus of 6.64 with a maximum nominal size of $12.5 \mathrm{~mm}$.. The shape of these particles was irregular and angular with a relatively high percentage of elongated particles and a very low percentage of flat particles.

Steel: Deformed high tensile steel bars of grade 360/520 with a nominal diameter of $16 \mathrm{~mm}$ were used as individual rebars and as embedded reinforcement with a yie ld stress of 450 MPa. Its mechanical characteristics satisfy the Egyptian Standard Specification (E.S.S. 262/ 1999) [38].

Pachin SYNTAL 909: It is synthetic enamel for exterior and interior uses based on modified non-yellowing alkyd resin, from the Pachin's industrial paints factory. Its mechanical properties as shown in Table (1) satisfy the Egyptian Standard Specification (E.S.S. 1757/2007) [39].

Pachin Saniton 900: It is alkyd paint for interior uses based on modified non -yellowing alkyd resin, from the Pachin's industrial paints factory with mechanical properties as shown in Table (2) satisfying the Egyptian Standard Specification (E.S.S. 1757/2007) [39].

Primer: Fast dry synthetic primer based on resin base, from the Pachin's industrial paints factory. Its mechanical properties as shown in Table (3) satisfy the Egyptian Standard Specification (E.S.S. 1757/2007) [7].

Under-coat: It is resin paint for steel surfaces protection, from Sika Company satisfying the E.S.S. 1757/2007 [39].

KIMAPOXY 131: The protection coating (anti rust paint) used was the KIMAPOXY 131, from the Chemicals for Modern Building International - CMB factory. Its chemical and physical characteristics satisfy the Egyptian Concrete Code of Practice (E.C.P. 203/2007) [40].

Concrete: Concrete mix was proportioned using ordinary Portland cement, crushed dolomite and graded sand. Standard concrete cubes of dimensions $15 \times 15 \times 15 \mathrm{~cm}$ with embedded steel bars were cast using concrete mix of $25.5 \mathrm{MPa}$ compressive strength with a mix ratio of 1 : 0.5: 2.067: 4.135 (cement: water: sand :dolomite) as shown in Table (5).

\subsection{Steel Rebar Specimens}

The $16 \mathrm{~mm}$ diameter rebars were cut into $17 \mathrm{~cm}$ length specimens classified as 7 groups each was painted by a different type of locally available isolation materia 1 in Egypt as shown 
in figure (2) and Table (6). Each group consists of 9 rebars divided into 3 groups. The first was used as rebars while the second was embedded in concrete cubes during casting process then tested after 28 days. The third group was embed ded also in concrete cubes.

The cross-sectional dimensions as shown in figure (1) and protection layer thicknesses of reinforcing steel bars before and after protection were represented in Table (7) and (9).

The first and third groups were immersed in 5\% concentration NaCL solution for 3 months. All steel rebars were connected to electrical cell to accelerate the corrosion process for a period of three months as shown in Figure (3). The individual rebars were left for about 1 year in an open air of ave rage temperature of 250 to $350 \mathrm{C}$ and average relative humidity of $25-30 \%$.

\subsection{Concrete Specimens}

In the test program reported herein, a total of 45 standard concrete cubes of dimensions $15 \times 15 \times 15 \mathrm{~cm}$ were cast. The materials proportions of the concrete mix used were represented in Table (5). Compressive strength tests were carried out by using $15 \times 15 \times 15 \mathrm{~cm}$ standard cubes. 42 cubes with embedded steel rebars were conducted to evaluate the bond strength before and after chloride attack (NaCL solution).

\subsection{Electrical Cell}

In this performed test program, an electrical cell was used to accelerate the corrosion process as shown in figure (3). The rebars used (individual and embedded rebars) were connected to the positive. At the steel reinforcing bars, ions leave the surface and pass into the water. Fresh atoms ionize to replace the desorbed ions. The iron bar corrodes. The electrons released by the ionised iron atoms flow through the connecting wire to the copper bar. At the cathode bar, the released electrons which have built up attract positive hydrogen ions. The hydrogen ions are adsorbed onto the bar's surface and then combine with the electrons to form hydrogen gas. The gas bubbles up and leaves the solution. The cathode bar does not corrode. It simply provides a surface where hydrogen ions can meet and combine with electrons [41].

Electrons keep on flowing round the wire until all the rebars has corroded away. Or until all the hydrogen ions in the solution have been used up, and no other positive ions are left which can take over their job. The corrosion effects of stray current can be easily demonstrated as follow, after passing a DC current in the cell containing a 5\% concentration NaCL solution, the formation of hydrogen bubbles is readily visible on the rebars connected to the negative post of the DC power supply while the rebars connected to the positive post shows signs of rapid corrosion.

Table 1. Technical information of Pachin SYNTAL 909 (as provided by manufacturer).

\begin{tabular}{|c|c|c|c|c|c|}
\hline Finish & Colors & $\begin{array}{c}\text { Solids } \\
\text { content (by } \\
\text { weight) }\end{array}$ & $\begin{array}{c}\text { Solids by } \\
\text { weight }\end{array}$ & $\begin{array}{c}\text { Specific } \\
\text { Gravity }\end{array}$ & Viscosity \\
\hline High gloss & $\begin{array}{c}\text { White \& as } \\
\text { Pachin color } \\
\text { fan }\end{array}$ & $52 \% \pm 2$ & $69 \% \pm 2$ & $1.12 \pm 0.03$ & $105-115$ K.U \\
\hline
\end{tabular}

Table 2. Technical information of Pachin Saniton 900 (as provided by manufacturer).

\begin{tabular}{|c|c|c|c|c|c|}
\hline Finish & Colors & $\begin{array}{c}\text { Solids } \\
\text { content (by }\end{array}$ & $\begin{array}{c}\text { Solids by } \\
\text { weight }\end{array}$ & $\begin{array}{c}\text { Specific } \\
\text { Gravity }\end{array}$ & Viscosity \\
\hline
\end{tabular}




\begin{tabular}{|c|c|c|c|c|c|}
\hline & & weight) & & & \\
\hline Matt & $\begin{array}{c}\text { White \& as } \\
\text { Pachin color } \\
\text { fan }\end{array}$ & $50 \% \pm 2$ & $74 \% \pm 2$ & $1.5 \pm 0.03$ & $100-110 \mathrm{~K} . \mathrm{U}$ \\
\hline
\end{tabular}

Table 3. Technical information of Pachin Primer (as provided by manufacturer).

\begin{tabular}{|c|c|c|c|c|c|}
\hline Finish & Colors & $\begin{array}{c}\text { Solids } \\
\text { content (by } \\
\text { weight) }\end{array}$ & $\begin{array}{c}\text { Solids by } \\
\text { weight }\end{array}$ & $\begin{array}{c}\text { Specific } \\
\text { Gravity } \\
\text { gm/.cm }\end{array}$ & Viscosity \\
\hline Flat & $\begin{array}{c}\text { Brown, } \\
\text { White and } \\
\text { yellow }\end{array}$ & $48 \%$ & $67 \%$ & 1.54 & $100-110$ K.U \\
\hline
\end{tabular}

Table 4. Technical information of KIMAPOXY 131 (as provided by manufacturer).

\begin{tabular}{|c|c|c|c|c|c|}
\hline \multirow{2}{*}{ Finish } & Colors & $\begin{array}{c}\text { Solids } \\
\text { content (by } \\
\text { weight) }\end{array}$ & $\begin{array}{c}\text { Specific } \\
\text { Gravity } \\
\mathrm{gm} / \mathrm{cm}^{3}\end{array}$ & \multicolumn{2}{|c|}{ Sitting Time } \\
\cline { 5 - 6 } & Initial & Final \\
\hline Flat & Gray & $76 \% \pm 1$ & $1.70 \pm 0.02$ & $8 \mathrm{hr}$. & $\begin{array}{c}24 \\
\mathrm{hr}\end{array}$ \\
\hline
\end{tabular}

Table 5. Properties of the concrete used

\begin{tabular}{|c|c|c|c|c|c|c|}
\hline $\begin{array}{c}\text { Cement } \\
\mathrm{kg} / \mathrm{m}^{3}\end{array}$ & W/C & $\begin{array}{l}\text { Sand } \\
\mathrm{kg} / \mathrm{m}^{3}\end{array}$ & $\begin{array}{c}\text { Dolomite } \\
\mathrm{kg} / \mathrm{m}^{3}\end{array}$ & $\begin{array}{c}\text { Slump } \\
(\mathrm{cm})\end{array}$ & $\mathbf{C}_{7}$ & $\mathrm{C}_{28}$ \\
\hline 316.71 & 0.5 & 654.63 & 1309.63 & 25 & 199 & 255 \\
\hline
\end{tabular}
$\mathbf{W} / \mathbf{C}=$ water to cement ratio.
$\mathbf{C}_{7}=$ compressive strength at 7 days $\left(\mathrm{kg} / \mathrm{cm}^{2}\right)$.
$\mathbf{C}_{\mathbf{2 8}}=$ compressive strength at 7 days $\left(\mathrm{kg} / \mathrm{cm}^{2}\right)$.

Table 6. Description of Samples.

\begin{tabular}{|c|c|}
\hline Code of sample & Description \\
\hline S & Control steel bars \\
\hline C & Cement mortar coating \\
\hline E & KIMAPOXY 131 coating \\
\hline P & Primer coating \\
\hline W & Pachin SYNTAL 909 \\
\hline M & Pachin Saniton 900 \\
\hline I & Under-coat \\
\hline
\end{tabular}

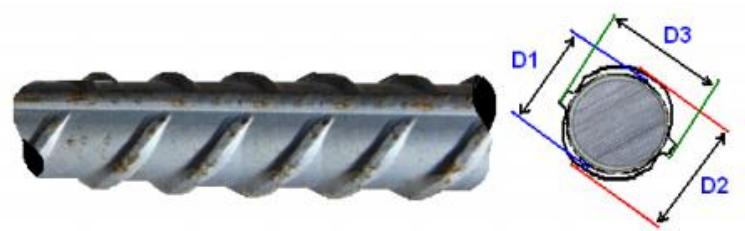

Figure 1. Dimensions of Reinforcing Bar. 
Table 7. Dimensions of Reinforcing Bar before Corrosion .

\begin{tabular}{|c|c|c|c|c|c|}
\hline $\begin{array}{c}\text { Painting/ Coating Material } \\
\text { Used }\end{array}$ & $\mathbf{D}_{\mathbf{1}}$ & $\mathbf{D}_{\mathbf{2}}$ & $\mathbf{D}_{\mathbf{3}}$ & $\begin{array}{c}\text { Average Coating } \\
\text { Thickness } \mathbf{~ m m}\end{array}$ & Comments \\
\hline Control & 15.8 & 17.45 & 18.25 & -- & -- \\
\hline Without Coating & 15.8 & 17.45 & 18.25 & 0.00 & -- \\
\hline KIMAPOXY 131 & 16.4 & 17.65 & 18.1 & 0.22 & -- \\
\hline Undercoat & 16.55 & 18 & 18.35 & 0.47 & -- \\
\hline Primer & 16.35 & 17.9 & 18.45 & 0.40 & Still coated \\
\hline Pachin SYNTAL 909 & 16.25 & 17.65 & 18.55 & 0.32 & -- \\
\hline Pachin Saniton 900 & 16.75 & 17.95 & 18.6 & 0.60 & Still coated \\
\hline Cement mortar & 16.55 & 18.2 & 19 & 0.75 & -- \\
\hline
\end{tabular}

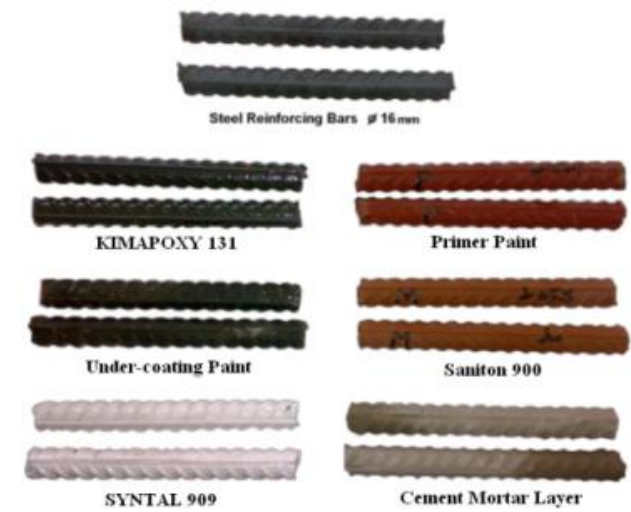

Figure 2. Reinforcing Bars of $16 \mathrm{~mm}$ Diameter which Coated using Different Types of Coating Materials Used.
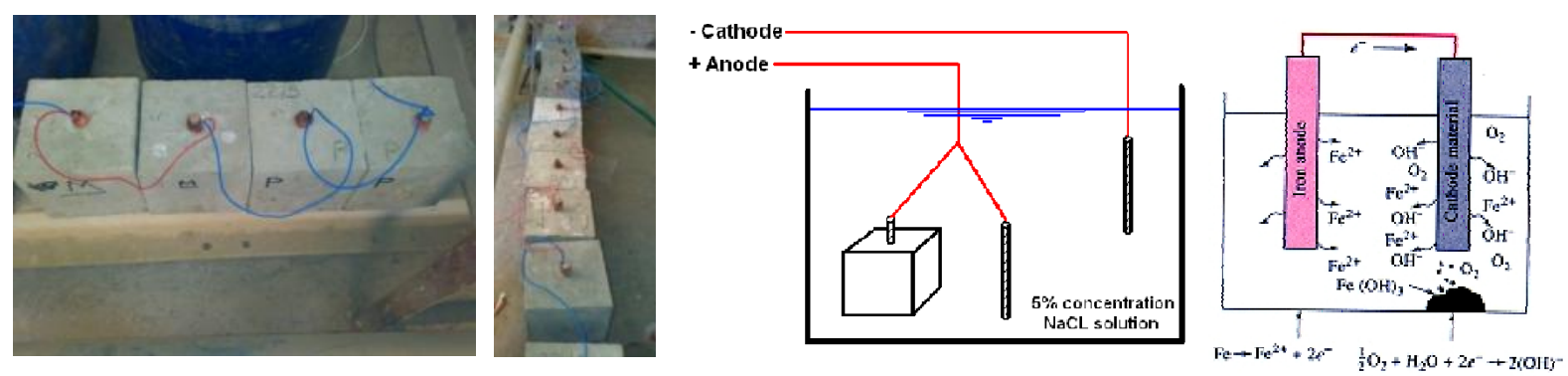

Figure 3. Electrical Circuit to Accelerate the Corrosion .

\section{ANALYSIS OF TEST RESULTS}


A summary of the test results is presented in Table s (8) and (9). Observed bond strength before and after corrosion of embedded rebars are presented in this paper and discussed in the following sections. The effect of corrosion on rebars after about 2 years in open air are also represented.

From Table (8) and Figure (5), it could be noted the remarkable effect of coating reinforcing bars with different locally available materials in Egypt.

It was noted that the decrease in dimensions were maximum when the steel rebars were not protected or coated with cement mortar. The protected rebars performed in a preferable manner than those not protected as shown in Table (8). The test results indicated that, the best recorded results were obtained for rebars protected with primer coating paint and Saniton 900 followed by KIMAPOXY 131 then SYNTAL 909 and finally for the rebars protected by under coat anti-rust coating paint.
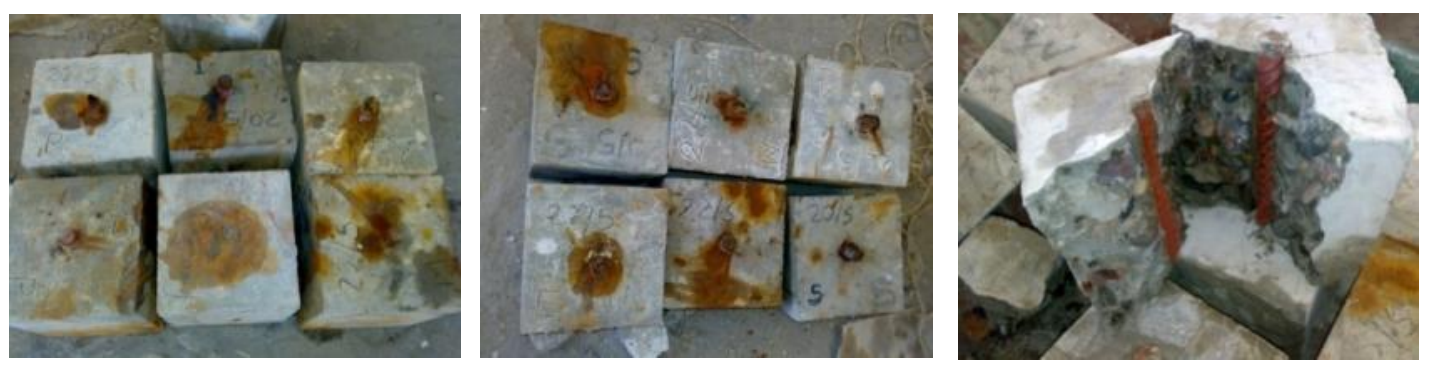

Figure 4. Embedded Reinforcing Bars after Corrosion .

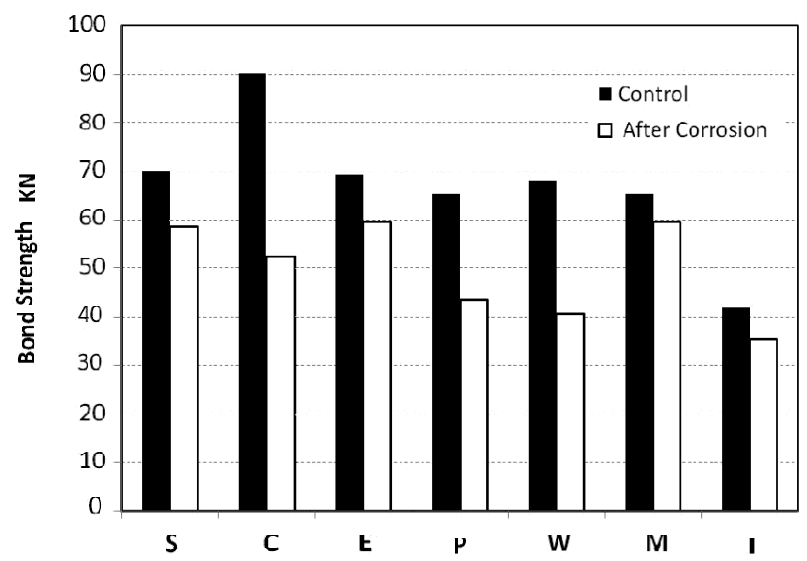

Figure 5. Comparison between Bond Strength before and after Corrosion.

Table 8. Comparison between Bond Strength before and after Corrosion.

\begin{tabular}{|l|l|l|}
\hline $\begin{array}{l}\text { Type of } \\
\text { sample }\end{array}$ & Control & After Corrosion \\
\hline
\end{tabular}




\begin{tabular}{|c|c|c|}
\hline $\mathbf{S}$ & 70.1 & 58.6 \\
\hline $\mathbf{C}$ & 90.2 & 52.4 \\
\hline $\mathbf{E}$ & 69.3 & 59.6 \\
\hline $\mathbf{P}$ & 65.3 & 43.5 \\
\hline $\mathbf{W}$ & 68.2 & 40.7 \\
\hline $\mathbf{M}$ & 65.3 & 59.6 \\
\hline $\mathbf{I}$ & 42 & 35.6 \\
\hline
\end{tabular}

Table 9. Reinforcing Bar Dimensions after Corrosion (Left for 3-months in water connected to Electrical Circuit then left in the open air for 2 years).

\begin{tabular}{|c|c|c|c|c|}
\hline Painting Material Used & \multirow{2}{*}{$\mathbf{D}_{\mathbf{1}}$} & $\mathbf{D}_{\mathbf{2}}$ & $\mathbf{D}_{\mathbf{3}}$ & $\begin{array}{c}\text { Average Decrease in } \\
\text { Diameter } \mathbf{~ m m}\end{array}$ \\
\hline Control & 15.8 & 17.45 & 18.25 & -- \\
\hline Without Coating & 15 & 15.2 & 16.4 & $\mathbf{- 1 . 6 3}$ \\
\hline KIMAPOXY 131 & 15.75 & 17.3 & 17.9 & $\mathbf{- 0 . 1 8}$ \\
\hline Undercoat & 14.85 & 17.4 & 17.3 & $\mathbf{- 0 . 6 5}$ \\
\hline Primer & 16.35 & 17.9 & 18.45 & $\mathbf{0}$ \\
\hline Pachin SYNTAL 909 & 14.9 & 17.1 & 18.05 & $\mathbf{- 0 . 4 8}$ \\
\hline Pachin Saniton 900 & 16.6 & 17.2 & 18.6 & $\mathbf{0}$ \\
\hline Cement mortar & 15.3 & 15.3 & 16.4 & $\mathbf{- 1 . 5 0}$ \\
\hline
\end{tabular}

\section{CONCLUSIONS}

This study is based on the values of cohesion between the rebars and concrete to study the feasibility of isolation before and after exposure to the rust (through submerged in pools of water electrolysis cell for 90 days in the presence of salts, concentration of 5\% NaCL).

The results of this study indicated that the use of insulation materials reduces the rate of chloride attack and corrosion process but it weakens the cohesion between rebars and concrete.

The bond strength test results indicated that, before the chloride attack, the best recorded values were obtained when using cement-coated rebars followed by not protected rebars the SYNTAL 909 protected rebars then primer paint followed by Saniton 900 paint and finally under-coat paint protection.

After chloride attack and rust formation, the recorded results indicated that the KIMAPOXY 131 and Saniton are the better offered isolation materials in the range of this study followed by other types. The lowest recorded values were recorded to the under-coat and SYNTAL 909 coating paints as a smooth thick layer were performed which decrease the cohesion between rebars and concrete.

Tested rebars which immersed in NaCL solution for three months then left at open air indicated that, the best results were obtained when using primer then KIMAPOXY 131 followed by Saniton and finally under -coat paint. Cement mortar coating layer is not effective 
as protective material but it is approves the cohesion between rebars and concrete in dry environment.

\section{RECOMMENDATIONS}

It is recommended the following when needs to protect steel reinforcing bars in order to isolate to reduce or prevent the formation of corrosion by using locally available coating materials in Egypt:

1. Recommended using anti-rust epoxy In the case of unavailability or low budget Economic may allow the use of lacquer stretch to tip the night to use the paint using anti -rust painting.

2. When there is a need to protect steel reinforcement by coating bars it should take into consideration fully painted and covered with insulating paint.

3. In the case of isolation of steel reinforcing bars after the appearance of rust it shall be remove the rust layer using a steel brush. After the removal of corrosion the coating process should performed immediately.

\section{REFERENCES}

1. Lundgren, K., 2007, "Effect of Corrosion on the Bond between Steel and Concrete : An Overview," Magazine of Concrete Research 59, no. 06 (2007), pp. 447-461.

2. Moreno, M.; Morris W.; Alvarez M.G.; and Duffo G.S., 2004, "Corrosion of Reinforcing Steel in Simulated Concrete Pore Solutions Effect of Carbonation and Chloride Content." Cement and Concrete Research 46 (2004), pp. 2681-2699.

3. Ed, P. M.; Chess, E.; and Spon, F. N., 1998, "Cathodic Protection of Steel in Concrete," New York, NY, pp.187.

4. Jones and Denny, A., 1996, "Principles and Prevention of Corrosion," Second Edition, Prentice Hall, Upper Saddle River, New Jersey, USA, pp.572.

5. Bentur, A.; Diamond, S.; and Berke, N. S., 1997, "Steel Corrosion in Concrete," New York, NY, USA, pp.201.

6. Arup H., 1983, "The Mechanisms of the Protection of Steel by Concrete, in Corrosion of Reinforcement in Concrete Construction," Hellis Horwood, Chichester, pp. 151-157.

7. Frederiksen, J.M. and HETEK, E., 1996, "Chloride Penetration into Concrete - State of the Art" Transport Processes, Corrosion Initiation, Test Methods and Prediction Models, the Road Directorate, Report no. 53, Copenhagen.

8. Pedeferri, P., 1996, Construction Build. Mater. 10 , p. 391

9. Melchers, R. E. and Li, C.Q., 2009, "Reinforcement corrosion initiation and activation times in concrete structures exposed to severe marine environments Original Research Article, Cement and Concrete Research, Volume 39, Issue 11, November 2009, pp. 1068 1076.

10.

Burke, D. F. and Hagen, M. G., 1994, "Performance of EpoxyCoated Rebar, Galvanized Rebar, and Plain Rebar with Calcium Nitrate in a Marine Environment," Concrete Reinforcing Steel Institute (CRSI), San Diego, California, USA.

11.

Vennesland, O. and Gjorv, O. E., "Fly Ash, Silica Fume, Slug \& Other Mineral By-Products in Concrete," Publication SP-American Concrete Institute 79, American Concrete Institute Vol. 2, Detroit, USA. Pp. 719-729.

12. Babaei, K. and Hawkins, N. M., 1991, "Symp. Corrosion Forms and Control for Infrastructures," ASTM Special Technical Publication No. 1137, ASTM, Philadelphia. PA, USA, pp.140-154. 
13.

Atkins, C.; Brueckner, R.; and Lambert, P., 2010, "Management of Corrosion of Infrastructure," Shreir's Corrosion, Volume 4, pp. 3198-3206.

14.

Schiessl, P. and Bakker, R., 1988, "Measures of Protection,"

Corrosion of Steel in Concrete, edit. Shiessl, P., Report of the Technical Committe e 60CSC RILEM, The International Union of Testing and Research Laboratories for Materials and Structures, Ch. 5, pp.73.

15.

Treadaway, K.W. J.; Brown, B. L.; and Cox, R.N., 1978, "Durability of Galvanized Steel in Concrete," Corrosion of Reinforcing Steel in Concrete, A symposium sponsored by ASTM Committee G -1 on Corrosion of Metals, pp.102-131.

16.

Hou, J.; Fu, X.; and Chung, D. D.L., 1997, "Improving Both

Bond Strength and Corrosion Resistance of Steel Rebar in Concrete by Water Immersion or Sandblasting of Rebar." Cement and Concrete Research. V. 27, No. 5, pp. 679-684.

17.

Murphy, K.; Zhang, S.; and Karbhari, V. M., 1999, "Effect of

Concrete Based Alkaline Solutions on Short Term Response of Composites," in

Proceedings of the 44th International Society for the Advancement of Material and Process Engineering Symposium and Exhibition, vol. 44, pp. 2222-2230.

18.

Wang, S. X.; Lin, W. W. ; Ceng, S.A.; and Zhang, J. Q., 1998,

"Corrosion Inhibition of Reinforcing Steel by Using Acrylic Latex," Cement and Concrete Research, Vol. 28, Issue 5, May 1998, Pages 649-653.

19.

Abu, Y. M. and Aoki, K., 2005, "Corrosion Protection by Polyaniline-Coated Latex Microspheres," Journal of Electro analytical Chemistry 583, pp. 133-139.

20.

Gjorv, O.E., 1995, "Effect of Condensed Silica Fume on Ste el Corrosion in Concrete," ACI MATERIALS JOURNAL, VOL 92, NUMBER 6, pp. 591598.

21.

Mullick, A.K., 2000, "Corrosion of Reinforcement in Concrete An Interactive Durability Problems," The Indian Concrete Journal, April 2000, Vol. 74, No 4, pp. 168-176.

22.

Seneviratne, A.M.G; Sergi, G.; and Page, C. L., 2000, "Performance Characteristics Of Surface Coatings Applied To Concrete For Control Of Reinforcement Corrosion," Original Research Article, Construction and Building Materials, Vol. 14, Issue 1, 28 February 2000, pp. 55-59.

23.

Page, C. L., 1997, "Cathodic Protection of Reinforced Concrete-Principles and Applications," In: Proceedings of the International Conference on Repair of Concrete Structures. From Theory to Practice in a Marine Environment, Svolvear (Norway) (28-30 May, 1997), pp. 123-131.

24.

EN 12696-1 Standard, 2000, "Cathodic Protection of Steel in Atmospherically Exposed Concrete," The European Standard,

25. Kranc, S. C.; Sagues, A. A.; and Presuel-Moreno, F. J., 1997, "Computational and Experimental Investigation of Cathodic Protection Distribution in Reinforced Concrete Marine Piling," Corrosion/97, paper no. 231, NACE, Houston, USA.

26.

Sagues, A. A.; Kranc, S. C.; and Presuel-Moreno, F.J., 1997, "Advanced Computational Model for Sacrificial Cathodic Protection of Partially Submerged Reinforced Concrete Marine Footers, in Repair and Rehabilitation of Reinforced Concrete Structures: the State of the Art," In: W.F. Silva-Araya, O.T. De Rincon and L.P. O'Neil, Editors, American Society of Civil Engineering, Reston, pp. 113. 
27.

Bertolini, L.; Bolzoni, F.; Pastore, T.; and Pedeferri, P., 1996, "New Experiences in Cathodic Prevention of Reinforced Concrete Structures," In: C.L. Page et al. Corrosion of Reinforcement in Concrete, Society of Chemical Industry, London, pp. 389-398.

28.

R. Myrdal, Embeddable Reference Electrodes for Concrete - A

State of the Art Report, European Federation of Corrosion, WP 11 Corrosion in Concrete, Task Group 5, Draft 3, August 2000.

29.

T. Pastore, P. Pedeferri, L. Bertolini and F. Bolzoni, Current distribution problems in the cathodic protection of reinforced concrete structures. In: D.W.S. Ho and F. Collins, Editors, Proceedings of the International RILEM/CSIRO/ACRA Confere nce on Rehabilitation of Concrete Structures, Melbourne (31 August-2 September, 1992), pp. 189-200.

30.

Luca Bertolini; Maddalena Carsana; and Pietro Pedeferri, 2000,

"Corrosion Behavior of Steel in Concrete in the Presence of Stray Current," Corrosion Science 49 (2007) 1056-1068

31. Reiner, L. and Bavarian, B., "Corrosion of Steel Rebar in Concrete," presented at the 14th NCUR, Missoula, Montana, USA. April.

32.

Chung, D. D. L., 2000, "Corrosion Control of Steel-Reinforced Concrete," Journal of Materials Engineering and Performance, Volume 9, Number 5, Solartron Instruments, 1997, "Understanding Electrochemical Cells - Technical Report 17 ," Solartron Group Ltd, Victoria Road, Farnborough, Hampshire, GU14 7PW, UK.

33. http://www.corrosion-doctors.org/Corrosion-Factors-Cells

[accessed at 5/7/2010].

34.

Pyc, W.A., R.E. Weyers and M.M. Sprinkel, 1998, "Corrosion Protection Performance of Corrosion Inhibitors and Epoxy -Coated Reinforcing Steel in a

Simulated Concrete Pore Water Solution," Report No. VTRC 98-R42, Virginia Transportation Research Council, USA, pp. 40.

35. E.S.S. No. 4756-1, 2006, "Cement ," Egyptian Standard Specifications, Ministry of Industry, Cairo, Egypt.

36. E.S.S. No. 1109, 2008, "Aggregate," Egyptian Standard Specification, Ministry of Industry, Cairo, Egypt.

37.

American Society for Testing and Materials (ASTM), 2002, "Standard Specification for Concrete Aggregates C 33-02a," Philadelphia, USA.

38. E.S.S. No. 262, 1999, "Reinforcing Bars ," Egyptian Standard Specifications, Ministry of Industry, Cairo, Egypt.

39. E.S.S. No. 1757, 2007, "Paints," Egyptian Standard Specification, Ministry of Industry, Cairo, Egypt.

40. Egyptian Code of Practice, 2007, "Design and Construction for Reinforced Concrete Structures -203/2007," Research Centre for Houses Building and Physical Planning, Cairo, Egypt.

41.

Kauffman, A. M., 1997, "Understanding Electrochemical Cells," Technical Report 17, Issue 2, http://www.solartron.com (accessed at 5/7/2010). 
